\title{
Öğretmen görüşlerine göre ilköğretim okul müdürlerinin örgütsel güç kaynaklarını kullanım düzeyleri $\left.{ }^{\star \star}\right]$
}

\author{
Hasan Basri MEMDUHOĞLU ${ }^{[* *]}$ \\ Mehmet TURHAN ${ }^{[* * *]}$
}

\section{Öz}

$\mathrm{Bu}$ çalışmada, öğretmen görüşlerine göre okul müdürlerinin yönetim sürecinde hangi örgütsel güç kaynaklarını kullandıkları ve bu sosyal güç kaynaklarını kullanım düzeyleri belirlenmeye çalışılmıştır. Betimsel tarama modelindeki çalışmanın örneklemini Van ve Siirt il merkezindeki kamu okullarında görev yapmakta olan 400 ilkokul ve ortaokul öğretmeni oluşmaktadır. Veriler Altınkurt ve Yılmaz (2013) tarafından geliştirilen “Okullarda Örgütsel Güç Ölçeği” ile toplanmıştır. Verilerin analizinde betimleme istatistikleri ve parametrik testler uygulanmıştır. Elde edilen bulgulara göre okul müdürlerinin en sık başvurdukları güç kaynağı uzmanlık gücü olurken en az kullandıkları güç kaynağı ise zorlayıcı güç olarak bulunmuştur. Okul müdürleri çoğunlukla yasal güç, ödül gücü, uzmanlık gücü ve karizmatik güçlerini kullanırken zorlayıcı güçlerini ise nadiren kullanmaktadırlar. Ortaokulda görev yapan müdürler ilkokul müdürlerine oranla yasal güç, ödül gücü, uzmanlık gücü ve karizmatik güçlerini daha sık kullandıklarını belirtmişlerdir.

Anahtar kelimeler: Güç, örgütsel güç, okul müdürü, okul yönetimi.

\section{Use levels of primary school principals' organizational power: what do teachers think?}

\begin{abstract}
In this study, it is aimed to identify which social power resources school principals use in management process and the levels of that use according to teachers' opinions. The study is a descriptive research study, using a survey model and its sample consisted of 357 primary and elementary teachers currently teaching in the cities of Van and Siirt. Data were collected through "The Organisational Power Scale" developed by Altınkurt and Yılmaz (2013). While analysing

[*] Bu makale, 8-10 Mayıs 2014 tarihlerinde Siirt’te gerçekleştirilen 9. Ulusal Eğitim Yönetimi adlı kongrede sözlü bildiri olarak sunulmuştur.

[*] Doç. Dr. Yüzüncü Yıl Üniversitesi, Eğitim Fakültesi, Eğitim Yönetimi Teftişi Planlaması ve Ekonomisi Bilim Dal. hasanmemduhoğlu@gmail.com

${ }^{[* *]}$ Arş. Gör. Yüzüncü Yıl Üniversitesi, Eğitim Fakültesi, Eğitim Yönetimi Teftişi Planlaması ve Ekonomisi Bilim Dal.. turhan5619@gmail.com
\end{abstract}


data, parametric tests were used, addition to descriptive statistics. According to the findings, principals most frequently used expert power and they used coercive power least frequently. According to teachers' opinion, while principals usually used legitimate power, reward power, expert power, and referent power, they rarely used coercive power. Compared to primary school teachers, elementary school teachers asserted that principals used their legitimate power, reward power, expert power, and referent power more frequently.

Keywords: Power, organizational power, school principals, school management.

\section{Giriş}

Örgütlerin yönetiminde yöneticilerin örgüt üyelerini etkileyebilmesi ve onları örgütün amaçları doğrultusunda yönlendirmeleri oldukça önemlidir. Yöneticiler çalışanları etkilemede çeşitli güç kaynaklarına başvurular. Yöneticilerin çalışanları harekete geçirmeleri, sahip oldukları etkileyebilme güçleri ile doğru orantılıdır (Şimşek, 2002). Bu anlamda örgütsel analizler yapanlar için kritik öneme sahip güç kavramının (Kearins, 1996) eğitim örgütlerinin yönetimindeki karşılığı ve taşıdığı anlam, gücün kaynakları ve okul yönetiminde okul yöneticilerinin hangi durumlarda ne tür güç kaynaklarını kullandıklarının belirlenmesi önemli görülmektedir.

Güç kavramının pratikte ve araştırmalarda hoş olmayan çağrışımlar yaptı̆̆ı söylenebilir (Robins ve Judge, 2013). Güç ne kadar hakimiyet kurma ve boyun eğme ile ilişkilendirilse de aslında örgütün sosyal amaçlarına ulaşmasını sağlayan bir kaynaktır (Cherie, 1992; akt. Özaslan ve Gürsel, 2008). Alanyazında güç kavramının birçok tanımını bulmak mümkündür. Raven (2008) gücü sosyal güç olarak görmüş ve güç figürünün değişimi gerçekleştirmek için uygun kaynakları kullanması olarak tanımlamıştır. Dahl’ın (1957) tanımına göre güç, "A’nın B üzerindeki normalde yapmayacağı bir şeyi yaptırma yetisidir”. Güç kavramını doğada insanlarda ya da bireyin bizzat kendisinde bir etki oluşturma yetisi olarak tanımlamak mümkündür (Gong, 2006). Günlük yaşamın hemen hemen her alanında oldukça sık kullanılan güç kavramı insanlara kendiliğinden yapmayacakları şeyleri yaptırabilmek şeklinde de tanımlanabilir (Steers, 1981). Weber (1968) ise gücü zorla harekete geçirme, diğerlerini de benzer şekilde hareket etmeye veya bu duruma uymaya zorlama olarak tanımlamıştır (Akt. English, 1992). Pfeffer'in (1992) güç tanımı ise "davranışları etkileme, olayların akışını değiştirme, direnişle başa çıkma ve insanların bu yönde hareket etmelerini sağlayarak onları kazanma yolunda potansiyel bir kabiliyet" şeklindedir. Koşar ve Çalık’a göre (2011) yöneticiler tarafından kullanılan farklı güç türleri örgüt kültürlerinin oluşma sürecinde de etki edebilmekte ve her örgüt kültürü üzerinde aynı etkiyle sonuçlanmayabilmektedir.

Güç kavramı tek bir kişiden bahsederken bir şey ifade etmez, (Pfeffer, 1981; akt. Can ve Çelikten, 2000) mutlaka bir etkileşim gerektirir. Güç bireyin başkasını etkileme yeteneğidir ve gücün kapsamı da etki altında olan birey tarafından belirlenir (Rollinson ve Broadfield, 2002). Fiske ve Berdahl' a göre (2007) güce sahip olmak bir bireyin başka birinin belli bir şekilde davranmasını, hareket etmesini sağlamaktır ve güç tohumu etkilenen tarafından ekilir. Dolayısıyla güçten etkilenen kişiler direniş gösterseler dahi uygulanan güç varlığını sürdürür. 
Bierstedt (1950) güç kavramının "olası" sıfatından türemesinin bir tesadüf olmadığını ifade eder ve gücün ortaya çıana kadar bir ihtimal ve olasılık olduğunu belirtir. Askeri bir saldırı ihtimali, saldırının kendisi kadar etkili olabilmektedir ya da bir sırrı açığa çıkarma şantajı, sırrın açığa çıkarılmasından daha korkutucu olabilmektedir. Bir işçi boykotu tehdidi (gerçekten uygulanırsa başarısız olma ihtimali de vardır), tek başına iş̧̧ilerin istediği sonuçları doğurabilir. Dahl’’n (1957) tanımı üzerinden gidilecek olursa, A kişisinin B kişisi üzerinde kullandığı sosyal güçlerin etkisi ancak B kişisinin etkilenme düzeyi ile belirlenir. Aynı okulda çalışan iki öğretmen okul müdürünün aynı davranışlarından farklı boyutlarda etkilenebilirler ve etkilenme düzeyleri okul müdürünün kullandığı örgütsel gücün kapsamını belirler. Diğer bir deyişle gücü mutlaka açık bir şekilde uygulamak gerekmez, kişinin kendisi üzerinde bir başkasının güç uygulama potansiyeli olduğuna inanması yeterlidir (Varoğlu, 2013; Özaslan ve Gürsel, 2008). Ryle (1949) "bilmek" ve "uygulamak" arasında önemli bir farkın bulunduğunu belirtir ve bilmek, sahip olmak, arzu etmek gibi kelimelerin belli bir hareketi değil bireyin sürekli bir eğilimini ifade ettiğini savunur (Akt. Wrong, 1968); benzer bir fark bir güce sahip olmak ve gücü işe koşmak arasında da vardır. Kongre liderlerinin başkanın ret edebileceği düşüncesiyle bir tasarıyı ertelemesi buna örneklik teşkil eder (Wrong, 1968).

Okul müdürlerinin etkili bir rehberlik yapabilmeleri, öğretmenlerin resmi görev ve sorumluluklarını yerine getirmelerini sağlayabilmeleri, gerekli durumlarda hak edenleri ödüllendirebilmeleriveya kişisel yetenekvebilgilerini kullanarakişyaptırabilmelerigerekmektedir. Diğer bir deyişle okulların bir amaç doğrultusunda harekete geçirilebilmeleri için müdürler öğretmenleri farklı yollarla etkileme ihtiyacı duyarlar. Bu sebeple okul müdürlerinin gücü ve güç kaynaklarını tanımaları, hangi durumlarda hangi güç kaynaklarından yararlanılabileceklerini bilmeleri gerekmektedir. Koşar ve Çalık’a göre (2011) yöneticiler ancak bu etkileme yollarını ve bunların doğru kullanımlarını tam ve eksiksiz olarak anlarlarsa sahip oldukları güçleri etkili ve verimli bir şekilde kullanabilirler. Bu yolların bazıları kaynağını otoriteden alırken (yasal güç, zorlayıcı güç ve ödül gücü) bazıları ise kaynağını doğrudan müdürün kişiliği ve saygınlığından alır (uzmanlık gücü ve karizmatik güç).

\section{Gücün kaynakları}

Yöneticiler örgütün devamlllığını sürdürmek ve gelişimini sağlamak üzere güç kaynaklarına başvurmalı ve çalışanları etkileyerek örgütü doğru istikamette yönlendirebilmelidir. Ancak, insanları etkilemenin birçok farklı yolu vardır ve bu yolların etkililiği de bireyden bireye değişebilmektedir. Ödüllendirmenin verimi arttırdığı, zorlamanın ise bazen ceza olarak algılandığı aşikardır (Çalışır, 2008). Ancak kimilerinin açık bir şekilde verilen bir emri dostça bir öneriye uymaktan daha kolay yerine getirebileceği gözden kaçırılmamalıdır. Bu bağlamda yöneticilerin kullandıkları güç kaynakları ve düzeyleri örgütün özelliklerine uygun olmak durumundadır.

Hit, Black ve Porter (2005) gücün kendiliğinden veya gizemli bir şekilde ortaya çıkan bir şey olmadığını, belirli ve teşhis edilebilir bir kaynağa dayandığını ifade etmektedir (Akt. Koşar ve Çalık, 2011). Literatürde güç kaynaklarına ilişkin birçok farklı sınıflandırma bulunmakla 
birlikte (Bayraktaroğlu, 2000; Bayrak, 2001; Can ve Çelikten, 2000) güç kaynaklarını beş boyutta toplayan French ve Raven’n sınıflandırmasının genel olarak kabul edildiği görülebilmektedir (Lunenburg, 2012; Bayrak, 2011; Rollinson ve Broadfield, 2002; Steers, 1981). Örgütsel güç kaynakları yöneticinin mevkiinden ve yetkisinden kaynaklı iken, kişisel güç kaynakları ise yöneticinin bireysel özellikleri ile ilintili olarak ortaya çıkmaktadır (Aslanargun, 2009). Pfeffer (2011) kişisel güç kaynaklarını etkin bir şekilde kullanmak isteyen birinin sahip olması gereken yedi özellik olduğunu ifade etmiş ve bu özellikleri hırs, enerji, yoğunlaşma, özbilinç, güven, empati, çatışmaları hoş görebilme kapasitesi ve zeka olarak sıralamıştır. Bu çalışmanın da temel aldığı French ve Raven'ın soyal güç sınıflandırması açısından zorlayıcı güç, yasal güç ve ödül gücü örgütsel güç kaynakları olarak, karizmatik güç ve uzmanlık gücü ise kişisel güç kaynakları kapsamında değerlendirilebilir (Erchul ve Raven, 1997; Robbins ve Judge, 2013; English, 1992; Rollinson ve Broadfield, 2002; Kirel, 1996).

Yasal güç. Yasal güç, kaynağını yetkili pozisyona ya da role sahip bireylerin diğerlerini etkilemek ve yönetmek için sahip oldukları resmi haktan, bu hakkın getirdiği değerler ve inançlardan alır (Faeth, 2004; Kırel, 2013). Yöneticinin bir pozisyona gelerek kazandığ ve o pozisyondaki yönetici tarafından kullanılan güç türüdür (Hunt, 1994; akt., Bayrak, 2001). Yöneticinin bulunduğu makam ya da mevki kaynaklı güç kaynağıdır ve otorite ya da yetki olarak da tanımlanabilir. Astlar yöneticinin emir verme yetkisinin ve kendilerinin de uyma zorunluluğunun olduğunu bilirler. Yasal gücün aşırı kullanımı beraberinde iş doyumsuzluğu, direnme ve çatışmaları da getirebilmektedir (Altınkurt ve Yılmaz, 2012). Yetki gücü yöneticinin ünvanını kaybetmesi, devretmesi durumunda doğrudan etkisini yitirir (Lunenburg, 2012).

Uzmanlık gücü. Bir astın, lideri tecrübeli veya bilgili algılaması uzmanlık gücüne işaret etmektedir. Bu algı bireylerin lideri kendisinden daha bilgili, yeterli ya da tecrübeli olduğu varsayımına dayanır. Lideri bu şekilde algılayan bir birey için lider yöneticiliğin gerekliliği olan planlama, eşgüdümleme, yöneltme gibi konularda yeterlidir (Mullins, 1996; akt. Meydan ve Polat, 2010). Okul yöneticilerinin alanlarında sahip oldukları deneyim ve bilgi birikimleri ile öğretmenleri örgütün çıkarları doğrultusunda harekete geçirmeleri uzmanlık gücüne başvurduklarını gösterir. Bu bağlamda düşünüldügünde "Bilgi güçtür” deyimi esas olarak önemli bir gerçekliğe vurgu yapmaktadır (Bayrak, 2011). Erchul ve Raven’a göre (1997) B’nin (çalışanın) belli bir alanda A’nın (yöneticinin) uzmanlığa ve bilgiye sahip olduğunu düşünmesi A’nın uzmanlık gücü olarak ifade edilir. Birgi (2006) ise uzmanlık gücünü liderin görev yönelimli olması, personeline kendini bilgi ve yeterlikle kabul ettirmesi olarak tanımlamıştır.

Karizma gücü. Karizma gücü çalışanlara yöneticinin kişiliğine, kişisel özelliklerine duyduğu hayranlık yoluyla ve imrendiği yöneticisi gibi hareket etme isteği ile iş yaptırtabilme yeteneğidir (Cross, 1986). Müdürlerin kişiliklerine, bireysel özelliklerine ve örnek davranışlar sergilemelerine bağlı olarak öğretmenler tarafından lider olarak algılanmalarıdır (Aslanargun, 2009). Karizmatik gücün kaynağı yöneticinin iletişim becerisi ve kişiliğidir. Bu gücü kullanabilen kişiler çevrelerince beğenilen, saygı duyulan ve model alınan kişilerdir. Ayrıca diğer bireyler üzerinde hiç bir baskı ve zorlama kullanılmadan ve sevgi, saygı ve güven temelinde işler yaptırıldığından oldukça etkili bir 
güç tipidir (Bayrak, 2001). Uzmanlık gücüne benzemekle beraber daha az gözetim gerektirmesi iki güç kaynağının ayrıcı özelliğidir (Altınkurt ve Yılmaz, 2012).

Zorlayıcı güç. Zorlayıcı güç, başarısızlık durumunda cezalandırmaya dayanır. Müdürün direktiflerine öğretmenlerin uymaması durumunda kontrol etme ve cezalandırmayı öngörür (Bakan ve Büyükbeşe, 2010). Zorlayıcı güçte gücü elinde tutan kişi (yönetici) işi çalışanı olumsuz yaptırımlarla/sonuçlarla tehdit ederek yaptırır ve işin yapılması çalışanların yöneticinin işin yapıldığına inanacağını bilmesine bağlıdır (Raven, 2008). Lunenburg’a göre (2012) zorlayıcı güç ile iş çıktıları arasında negatif yönlü bir ilişki vardır bu yüzden zorlayıcı güce çok başvurulması tavsiye edilmemektedir. Okullarda fiziki güç, uyarı cezası, işten atılma ve disiplin soruşturması gibi doğrudan olumsuzluk içeren eylemlere başvurulması ya da ödül, ek ders ve izin gibi olumlu durumların ortadan kaldırılması zorlayıcı güce örnek verilebilir (Aslanargun, 2009).

Ödül gücü. Ödül gücü zorlayıcı gücün zıttıdır (Bakan ve Büyükbeșe, 2010) ve müdürün öğretmenleri istenen davranışları göstermeleri karşılığında ödüllendirme gücü olarak açıklanabilir. Ödül gücü kaynağını çalışanın istenileni yapması karşıllğ̆ında yöneticinin sunduğu maaşta artış, terfi ya da özel ayrıcalıklar gibi olumlu teşviklerden alır (Raven, 2008). Ödüller ne kadar adil dağıtılır ve çekici olursa ödül gücünün de o denli güçlü olması beklenir. Ödüllerin adaletli dağıtılmadığı algısı, bu gücü zorlayıcı güce dönüştürebilir (Altınkurt ve Yılmaz, 2012). Örgüt içinde astlar verilen görevleri ödüle (olumlu duruma) ulaşmak için yapıyorlarsa ödül gücünün, cezadan kaçmak için yapıyorsa zorlayıcı gücün etkin olduğu söylenebilir. Erchul ve Ravena (1997) göre ödül gücü ve zorlayıcı gücün etkili olabilmesi için mutlaka denetimin olması gerekir; diğer güç kaynaklarında ise denetim, gücün etkisinin korunması için gerekmeyebilir ve önemsizdir. Bununla birlikte verilen ceza veya ödülün kapsamı da önemlidir. Başarıya karşıllk küçük ödüllerin, başarısızlığa karşllık ise büyük cezaların uygulandığı bir örgüt ile başarıya büyük ödüller, başarısızlığa ise küçük cezaların verildiği bir örgüte çalışanların bakış açıları oldukça farklılaşabilmektedir.

Güç kaynaklarının daha anlaşılır olarak ortaya konması amacıyla Tablo l'de güç kaynaklarına ilişkin bazı örnekler verilmiştir (Raven, 2008).

Tablo I

Güç Kaynaklarına Illişkin Örnek Cümleler

\begin{tabular}{|l|l|}
\hline Güç Kaynağı & Güç Kaynaklarına İlişkin Örnek Cümleler \\
\hline Yasal güç & "Sonuçta o benim amirim ve istediği işleri yapmalıyım." \\
\hline Uzmanlık gücü & $\begin{array}{l}\text { "Yöneticim bu konuda oldukça deneyim sahibi, yani ben sebebini tam anlamamış olsam da } \\
\text { o muhtemelen haklıdır." }\end{array}$ \\
\hline Zorlayııı güç & "İşi yaptım çünkü yapmazsam ceza alacağım söylendi." \\
\hline Karizmatik güç & "Yöneticime gerçekten hayranlık duyuyorum, keşke onun gibi olabilseydim." \\
\hline Ödül gücü & "İşi yaptım çünkü yaparsam ödül alacağım söylendi." \\
\hline
\end{tabular}


Çalışanların verilen görevleri istekle yapması olarak açıklanan "üstlenme" davranışını sergileyebilmeleri için yöneticilerin daha çok uzmanlık ve karizmatik güçlerini kullanmaları önerilmektedir. Yasal güç ve ödül gücünün kullanımı ise istekle olmasa bile asgari ölçüde çalışanların verilen görevleri yerine getirmelerini sağlamaktadır. Zorlayıcı gücün yüksek düzeyde kullanılması ise işten kaçınmalara ve itaatsizliğe yol açabilmektedir.

\section{Araştırmanın amacı}

Tarama modelindeki bu araştırmanın temel amacı ilkokul ve ortaokul müdürlerinin kullandıkları örgütsel güç kaynaklarına ve bu güçleri kullanma düzeylerine ilişkin öğretmen görüşlerini belirlemektir. Bununla birlikte müdürlerin güç kullanma düzeylerine ilişkin öğretmen görüşlerinin cinsiyet, kıdem yıll, branş, okul türü ve ikamet edilen şehir değişkenlerine göre farklılaşıp farklılaşmadığını ortaya koymak araştırmanın diğer bir amacıdır.

\section{Yöntem}

Bu bölümde araştırmanın modeli, evren ve örneklem, verilerin toplanması ve çözümlenmesine yer verilmiştir.

\section{Araştırma modeli}

İlköğretim okul müdürlerinin hangi güç kaynaklarını ne düzeyde kullandıklarını belirlemeyi amaçlayan bu çalışma tarama (betimsel) modelindedir. Bir grubun var olan belirli özelliklerini veya var olan bir durumu olduğu gibi betimlemeyi amaçlayan araştırmalar genel tarama araştırmaları olarak tanımlanır (Karasar, 2008; Büyüköztürk, Çakmak, Akgün, Karadeniz ve Demirel, 2013).

\section{Evren ve örneklem}

Araştırmanın evrenini, Van ilinin Tuşpa ve İpekyolu ilçeleri ve Siirt il merkezinde yer alan kamu ilköğretim okullarında görev yapan toplam 6018 öğretmen oluşturmaktadır. Buna göre araştırmanın örneklemi, Van’nn Tuşba ve İpekyolu ilçeleri ile Siirt il merkezinde yer alan kamu ilköğretim okullarında görev yapan 400 öğretmenden oluşmaktadır. Örneklem seçiminde, basit seçkisiz örnekleme tekniği kullanılmıştır. Tablo 2'de katılımcı öğretmenlerin kişisel bilgileri gösterilmiştir. 
Marmara Üniversitesi Atatürk Eğitim Fakültesi Eğitim Bilimleri Dergisi / Journal of Educational Sciences YIl: Haziran 2016 • Cilt-Sayı $44 \cdot$ ISSN: I300-8889 • ss. 73-89

Tablo 2

Örneklem Grubundaki Öğretmenlere Ilişkin Kişisel Bilgiler

\begin{tabular}{|l|l|c|c|}
\hline Değişken & Düzey & $\mathbf{n}$ & \% \\
\hline \multirow{3}{*}{ Cinsiyet } & Kadın & 138 & 38.7 \\
\cline { 2 - 4 } & Erkek & 219 & 61.3 \\
\hline \multirow{3}{*}{ Branş } & Sinıf & 144 & 40.3 \\
\cline { 2 - 4 } & Diğer Branşlar & 213 & 59.7 \\
\hline \multirow{3}{*}{ Okul Türü } & İlkokul & 161 & 45.1 \\
\cline { 2 - 4 } & Ortaokul & 196 & 54.9 \\
\hline \multirow{3}{*}{ Kıdem } & $1-2$ yll & 99 & 27.7 \\
\cline { 2 - 4 } & $3-6$ yll & 97 & 27.2 \\
\cline { 2 - 4 } & $7-10$ yll & 56 & 15.7 \\
\cline { 2 - 4 } & 11 yll ve üzeri & 102 & 28.6 \\
\hline \multirow{3}{*}{ Şehir } & Siirt & 188 & 52.7 \\
\cline { 2 - 4 } & Van & 169 & 47.3 \\
\hline
\end{tabular}

Tablo 2’de görüldüğü gibi katılımcıların 99'u 1 ya da 2 yıllık öğretmenlerdir ve toplam katılımcıların \% 27,7'sini oluşturmaktadır. Mesleki deneyiminin 3., 4., 5. ve 6. yılında olan katılımcı sayısı ise 97'dir. 11 yıl ya da daha fazla süredir görev yapan katılımcılar da 102 kişi ile toplam sayının \% 28,6'sını oluşturmaktadır. Araştırmanın yapıldığı her iki ilde de yoğun öğretmen sirkülasyonunun yaşanması, genç ve göreve yeni başlamış öğretmenlerin toplam katılımcılar arasında önemli bir bölümünü teşkil etmesini açıklamaktadır. Bunun bir diğer sebebinin ise göreve yeni başlayan öğretmenlerin araştırmalara katılımda daha hevesli ve istekli hareket ettikleri olduğu söylenebilir. Ayrıca katılımcıların çoğu branş öğretmeni ve erkektir. Şehir ve okul kademesine göre de oranlar birbirine yakındır.

\section{Verilerin toplanması ve çözümlenmesi}

Araştırma verilerinin toplanmasında, Yllmaz ve Altınkurt (2013) tarafindan geliştirilen "Okullarda Örgütsel Güç” ölçeği kullanılmıştır. Beş faktörlü bir yapıya sahip olan ölçek toplam varyansın \%66.61'ini açıklamaktadır. Ölçeğin alt boyutları için yeniden hesaplanan Cronbach Alfa katsayıları sırasıyla; yasal güç için .779, ödül gücü için .875, zorlayıcı güç için .846, uzmanlık gücü için .951 ve karizmatik güç için .961 olarak bulunmuştur. Toplam 400 ölçek dağıtılmış ve geri dönen ölçeklerden kullanılabilir durumda olan 357 ölçek değerlendirilmeye alınmıştır. Verilerin çözümlenmesinde betimleme istatistiklerinin (yüzde, frekans, aritmetik ortalama, standart sapma) yanında; bazı değişkenlere (yaş, cinsiyet, branş, mesleki kıdem) göre anlamlı farklılığın olup olmadığını belirlemek amacıyla İlişkisiz t-Testi ve Tek Yönlü Varyans Analizi (ANOVA) uygulanmıştır. ANOVA sonucuna göre farklılaşmanın hangi gruplar arsında olduğunu belirlemek içinse Post Hoc Testi (Scheffe) uygulanmıştır. 


\section{Bulgular}

Bu bölümde okul müdürlerinin kullandıkları güç kaynaklarına ilişkin ilköğretim okullarında görev yapan öğretmen görüşlerine yer verilmiştir.

\section{Okul müdürlerinin güç kullanım düzeylerine ilişkin bulgular}

Katılımcı öğretmen görüşlerine göre okul müdürlerinin güç kullanım düzeylerine ilişkin görüşlerinin örgütsel güç kaynakları ölçeğinin alt boyutlarında nasıl olduğuna ilişkin betimsel istatistik sonuçları tablo 3'te verilmiştir.

Tablo 3

Öğretmenlerin Örgütsel Bağ/lıklarına Illişkin Görüşlerinin Alt boyutlarda Aritmetik Ortalama ve Standart Sapma Değerleri

\begin{tabular}{|l|c|c|c|}
\hline Altboyutlar & $\mathbf{N}$ & $\bar{X}$ & ss \\
\hline Yasal Güç & 357 & 3,70 &, 81 \\
\hline Ödül Gücü & 357 & 3,51 &, 96 \\
\hline Zorlayıcı Güç & 357 & 2,33 &, 87 \\
\hline Uzmanlık Gücü & 357 & 3,78 &, 99 \\
\hline Karizmatik Güç & 357 & 3,59 & 1,12 \\
\hline
\end{tabular}

Tablo 3’te görüldüğü üzere, katılımcı öğretmenler okul müdürlerinin yasal gücü ( $\bar{X}=3,70)$, ödül gücü $(\bar{X}=3,51)$, uzmanlık gücü $(\bar{X}=3,78)$ ve karizmatik gücü $(\bar{X}=3,59)$ "çoğunlukla" kullandıklarını belirtmişlerdir. Ayrıca, öğretmen görüşlerine göre okul müdürleri zorlayıcı güçlerini ( $\bar{X}=2,33)$ "çok nadir" kullanmaktadırlar. Öğretmenlere göre müdürler sırasıyla en fazla uzmanlık gücü, yasal güç, karizmatik güç ve ödül gücünü kullanırken, zorlayıcı güç müdürler tarafından en az kullanılan güç kaynağıdır.

\section{Kişisel değişkenlere ilişkin bulgular}

Araştırmaya katılan öğretmenlerin müdürlerinin güç kullanma düzeylerine ilişkin görüşlerinin cinsiyet, branş, görev yaptığı okul türü ve şehir değişkenlerine göre farklılaşıp farklılaşmadığını belirlemek için yapılan t-testinden elde edilen bulgular tablo 4, 5, 6 ve 7’de verilmiştir. 
Marmara Üniversitesi Atatürk Eğitim Fakültesi Eğitim Bilimleri Dergisi / Journal of Educational Sciences Yıl: Haziran 2016 • Cilt-Sayı 44•ISSN: I300-8889 • ss. 73-89

\section{Tablo 4}

Cinsiyet Değişkenine Ilişkin t-Testi Sonuçları

\begin{tabular}{|l|l|c|c|c|c|c|c|}
\hline Değişken & Kategori & $\mathbf{N}$ & & ss & sd & $\mathbf{t}$ & $\mathbf{p}$ \\
\hline \multirow{2}{*}{ Yasal Güç } & Kadın & 138 & 3.75 & .789 & 355 & .878 & .375 \\
\cline { 2 - 8 } & Erkek & 219 & 3.67 & .834 & & & \\
\hline \multirow{2}{*}{ Ödül Gücü } & Kadın & 138 & 3.45 & .961 & 355 & -.966 & .335 \\
\cline { 2 - 8 } & Erkek & 219 & 3.55 & .959 & & & \\
\hline \multirow{2}{*}{ Zorlayıcı Güç } & Kadın & 138 & 2.33 & .900 & 355 & .049 & .962 \\
\cline { 2 - 8 } & Erkek & 219 & 2.33 & .860 & & & \\
\hline \multirow{2}{*}{ Uzmanlık Gücü } & Kadın & 138 & 3.78 & .976 & 355 & .006 & .995 \\
\cline { 2 - 8 } & Erkek & 219 & 3.78 & 1.010 & & & \\
\hline \multirow{2}{*}{ Karizmatik Güçç } & Kadın & 138 & 3.55 & 1.124 & 355 & -.480 & .632 \\
\cline { 2 - 8 } & Erkek & 219 & 3.61 & 1.125 & & & \\
\hline
\end{tabular}

Tablo 4'te görüldüğü gibi öğretmenlerin, okul müdürlerinin güç kullanma düzeylerine ilişkin görüşleri cinsiyet değişkenine göre; yasal güç $(\mathrm{t}=.878 ; \mathrm{p}>.05)$ ödül gücü $(\mathrm{t}=-.966 ; \mathrm{p}>.05)$ zorlayıcı güç ( $\mathrm{t}=.049 ; \mathrm{p}>.05)$ uzmanlık gücü $(\mathrm{t}=.006 ; \mathrm{p}>.05)$ ve karizmatik güç $(\mathrm{t}=-.480 ; \mathrm{p}>.05)$ alt boyutlarında anlamlı bir farklılık göstermemektedir. Diğer bir ifadeyle müdürlerin güç kullanım düzeylerine ilişkin öğretmen görüşleri, cinsiyet değişkenine göre farklılaşmamaktadır.

\section{Tablo 5}

Branş Değişkenine Ilişkin t-Testi Sonuçları

\begin{tabular}{|l|l|c|c|c|c|c|c|}
\hline Değişken & Kategori & $\mathbf{N}$ & & ss & sd & $\mathbf{t}$ & $\mathbf{p}$ \\
\hline \multirow{2}{*}{ Yasal Güç } & Sinıf & 144 & 3.47 & .918 & 355 & -4.336 & .000 \\
\cline { 2 - 8 } & Branş & 213 & 3.86 & .700 & & & \\
\hline \multirow{2}{*}{ Ödül Gücü } & Sınıf & 144 & 3.31 & 1.012 & 355 & -3.088 & .002 \\
\cline { 2 - 8 } & Branş & 213 & 3.64 & .903 & & & \\
\hline \multirow{2}{*}{ Zorlayıc1 Güç } & Sinıf & 144 & 2.35 & .802 & 355 & .261 & .794 \\
\cline { 2 - 8 } & Branş & 213 & 2.32 & .922 & & & \\
\hline \multirow{2}{*}{ Uzmanlık Gücü } & Sinıf & 144 & 3.53 & 1.086 & 355 & -3.942 & .000 \\
\cline { 2 - 8 } & Branş & 213 & 3.95 & .893 & & & \\
\hline \multirow{2}{*}{ Karizmatik Güç } & Sinıf & 144 & 3.41 & 1.193 & 355 & -2.518 & .0012 \\
\cline { 2 - 8 } & Branş & 213 & 3.71 & 1.060 & & & \\
\hline
\end{tabular}

Tablo 5'te belirtildiği üzere müdürlerin güç kullanım düzeyleri hakkındaki öğretmen görüşleri yasal güç $(t=-4.336 ; \mathrm{p}<.05)$, ödül gücü $(\mathrm{t}=-3.088 ; \mathrm{p}<.05)$, uzmanlık gücü $(\mathrm{t}=-3.942$; $\mathrm{p}<.05)$ ve karizmatik güç $(\mathrm{t}=-2.518 ; \mathrm{p}<.05)$ alt boyutlarında farklılaşmaktadır. Branş öğretmenleri sınıf öğretmenlerine göre müdürlerin yasal, ödül, uzmanlık ve karizmatik güçlerini kullanma düzeylerinin daha yüksek olduğunu belirtmişlerdir. Zorlayıcı güç alt boyutunda ise branş değişkenine göre katılımcı görüşleri arasında anlamlı bir farklılık görülmemektedir. 
Tablo 6

Okul Türü Değişkenine Ilişkin t-Testi Sonuçlan

\begin{tabular}{|c|c|c|c|c|c|c|c|}
\hline Değişken & Kategori & $\mathbf{N}$ & & ss & sd & $\mathbf{t}$ & $\mathrm{p}$ \\
\hline \multirow{2}{*}{ Yasal Güç } & İlkokul & 161 & 3.51 & .898 & 355 & -3.991 & .000 \\
\hline & Ortaokul & 196 & 3.86 & .708 & & & \\
\hline \multirow{2}{*}{ Ödül Gücü } & İlkokul & 161 & 3.40 & 1.004 & 355 & -1.861 & .064 \\
\hline & Ortaokul & 196 & 3.59 & .916 & & & \\
\hline \multirow{2}{*}{ Zorlayıcı Güç } & İlkokul & 161 & 2.29 & .806 & 355 & -.894 & .372 \\
\hline & Ortaokul & 196 & 2.37 & .927 & & & \\
\hline \multirow{2}{*}{ Uzmanlık Gücü } & İlkokul & 161 & 3.64 & 1.084 & 355 & -2.475 & .014 \\
\hline & Ortaokul & 196 & 3.90 & .902 & & & \\
\hline \multirow{2}{*}{ Karizmatik Güç } & İlkokul & 161 & 3.52 & 1.186 & 355 & -1.115 & .266 \\
\hline & Ortaokul & 196 & 3.65 & 1.069 & & & \\
\hline
\end{tabular}

Okul türü değişkenine göre öğretmen görüşlerinde yasal güç $(t=-3.991 ; \mathrm{p}<.05)$ ve uzmanlık gücü $(\mathrm{t}=-2.475 ; \mathrm{p}<.05)$ alt boyutlarında anlamlı bir farklılık tespit edilmiştir. Ortaokulda görev yapan katılımcılar ilkokul öğretmenlerine göre müdürlerinin yasal ve uzmanlık güçlerini daha fazla kullandıklarını belirtmişlerdir. Bununla birlikte, öğretmen görüşleri ödül gücü ( $\mathrm{t}=-1.861$; $\mathrm{p}>.05)$, zorlayıcı güç $(\mathrm{t}=-.894 ; \mathrm{p}>.05)$ ve karizmatik güç $(\mathrm{t}=-1.115 ; \mathrm{p}>.05)$ alt boyutlarında okul türü değişkenine göre benzeşmektedirler. Diğer bir değişle müdürlerin ödül, zorlayıcı ve karizmatik güçlerini kullanma düzeyleri ile ilgili hem ilkokul hem de ortaokul öğretmenleri benzer görüşler belirtmişlerdir.

\section{Tablo 7}

Şehir Değişkenine Illişkin t-Testi Sonuçları

\begin{tabular}{|c|c|c|c|c|c|c|c|}
\hline Değişken & Kategori & $\mathbf{N}$ & & ss & sd & $\mathbf{t}$ & $\mathrm{p}$ \\
\hline \multirow{2}{*}{ Yasal Güç } & Siirt & 188 & 3.64 & .866 & 355 & -1.67 & .095 \\
\hline & Van & 169 & 3.78 & .754 & & & \\
\hline \multirow{2}{*}{ Ödül Gücü } & Siirt & 188 & 3.53 & .946 & 355 & .377 & .706 \\
\hline & Van & 169 & 3.49 & .978 & & & \\
\hline \multirow{2}{*}{ Zorlayıcı Güç } & Siirt & 188 & 2.31 & .863 & 355 & -.539 & .590 \\
\hline & Van & 169 & 2.36 & .889 & & & \\
\hline \multirow{2}{*}{ Uzmanlık Gücü } & Siirt & 188 & 3.76 & 1.015 & 355 & -.482 & .630 \\
\hline & Van & 169 & 3.81 & .976 & & & \\
\hline \multirow{2}{*}{ Karizmatik Güç } & Siirt & 188 & 3.60 & 1.135 & 355 & .262 & .793 \\
\hline & Van & 169 & 3.57 & 1.114 & & & \\
\hline
\end{tabular}

Araştırmanın gerçekleştirildiği Van ve Siirt illerinde görev yapan öğretmenler, müdürlerin güç kullanma düzeylerine ilişkin benzer görüşlere sahiptirler. Şehir değişkenine göre müdürlerin yasal güç ( $\mathrm{t}=-1.673 ; \mathrm{p}>.05)$, ödül gücü $(\mathrm{t}=.377 ; \mathrm{p}>.05)$, zorlayıcı güç $(\mathrm{t}=-.539 ; \mathrm{p}>.05)$, uzmanlık 
gücü ( $\mathrm{t}=-.482 ; \mathrm{p}>.05)$ ve karizmatik güçlerini $(\mathrm{t}=.262 ; \mathrm{p}>.05)$ kullanma düzeylerine ilişkin öğretmen görüşleri farklılaşmamaktadır.

Kıdem değişkeninin katılımcı öğretmen görüşleri üzerinde anlamlı bir faklıllğa yol açıp açmadığını belirlemek için yapılan ANOVA testi sonuçları Tablo 8'de verilmiştir.

\section{Tablo 8}

\section{Kıdem Değişkenine llişkin ANOVA Testi Sonuçlan}

\begin{tabular}{|c|c|c|c|c|c|c|c|c|c|c|}
\hline Değișken & Düzey & n & & ss & Kare. Top. & sd & kareler ort. & $\mathrm{F}$ & $\mathbf{P}$ & Fark \\
\hline \multirow{4}{*}{ Yasal Güç } & $1-2$ yil & 99 & 3.86 & .719 & 6.328 & 3 & 2.109 & 3.200 & .023 & $1-2$ \\
\hline & 3-6 yıl & 97 & 3.51 & .885 & 230.694 & 350 & .659 & & & \\
\hline & 7-10 yil & 56 & 3.78 & .683 & 237.023 & 353 & & & & \\
\hline & 11 ve üzeri & 102 & 3.71 & .884 & & & & & & \\
\hline \multirow{4}{*}{ Ödül Gücü } & $1-2 \mathrm{yll}$ & 99 & 3.65 & .877 & 9.045 & 3 & 3.015 & 3.332 & .020 & $1-4$ \\
\hline & 3-6 yıl & 97 & 3.54 & .887 & 316.682 & 350 & .905 & & & \\
\hline & 7-10 y1l & 56 & 3.65 & .903 & 325.727 & 353 & & & & \\
\hline & 11 ve üzeri & 102 & 3.27 & 1.093 & & & & & & \\
\hline \multirow{4}{*}{ Zorlayıcı Güç } & $1-2$ yll & 99 & 2.20 & .821 & 5.063 & 3 & 1.688 & 2.223 & .085 & \\
\hline & 3-6 y1l & 97 & 2.44 & .925 & 265.735 & 350 & .759 & & & \\
\hline & 7-10 yll & 56 & 2.19 & .904 & 270.798 & 353 & & & & \\
\hline & 11 ve üzeri & 102 & 2.43 & .845 & & & & & & \\
\hline \multirow{4}{*}{ Uzmanlık Gücü } & $1-2$ yll & 99 & 3.87 & .928 & 5.527 & 3 & 1.842 & 1.865 & .135 & \\
\hline & 3-6 yil & 97 & 3.73 & .984 & 345.702 & 350 & .988 & & & \\
\hline & 7-10 yll & 56 & 3.97 & .957 & 351.229 & 353 & & & & \\
\hline & 11 ve üzeri & 102 & 3.62 & 1.079 & & & & & & \\
\hline \multirow{4}{*}{ Karizmatik Güç } & $1-2$ yil & 99 & 3.72 & .971 & 6.499 & 3 & 2.166 & 1.716 & .163 & \\
\hline & 3-6 yıl & 97 & 3.58 & 1.124 & 441.726 & 350 & 1.262 & & & \\
\hline & 7-10 yll & 56 & 3.71 & 1.204 & 4448.225 & 353 & & & & \\
\hline & 11 ve üzeri & 102 & 3.39 & 1.210 & & & & & & \\
\hline
\end{tabular}

Tablo 8’te görüldüğü üzere, araştırmaya katılan öğretmen görüşleri arasında; mesleki kıdemlerine göre yasal güç $(\mathrm{F}=3.200 ; \mathrm{p}<.05)$ ve ödül gücü $(\mathrm{F}=3.332 ; \mathrm{p}<.05)$ alt boyutlarında anlamlı bir farklılaşma bulunmaktadır. Buna göre mesleki kıdem yılı 1 veya 2 yıl olan öğretmenler 3-6 yıldır görev yapan öğretmenlere göre müdürlerin yasal güçlerini, 11 ve üzeri yıldır görev yapan öğretmenlere göre ise müdürlerin ödül gücünü daha sık kullandıklarını belirtmişlerdir. Bununla birlikte tüm mesleki kıdem gruplarındaki öğretmenler müdürlerin zorlayıcı ( $\mathrm{F}=2.223$; $\mathrm{p}>$.05), uzmanlık $(\mathrm{F}=1.865 ; \mathrm{p}>.05)$ ve karizmatik $(\mathrm{F}=1.716 ; \mathrm{p}>.05)$ güç kullanım düzeylerine ilişkin benzer görüşlere sahiptirler. 


\section{Tartışma ve sonuç}

Yöneticilik iş yaptırabilme sanatıdır. Yöneticilerin diğer çalışanları etkileyebilmeleri ve harekete geçirmeleri için bir liderlik vasfı ve çatışma çözme mekanizması olan güç kaynaklarını (Deniz ve Çolak, 2008), avantajları ve dezavantajlarılla birlikte bilmeleri; doğru yerde, doğru zamanda, doğru güç kaynağına başvurmaları oldukça önemlidir. İlköğretim öğretmenlerinin görüşlerine göre okul müdürlerinin sosyal güç kaynaklarını kullanma düzeylerini belirlemeyi amaçlayan bu çalışmada okul müdürlerinin sırasıyla en çok uzmanlık gücü, yasal güç, karizmatik güç, ödül gücü ve zorlayıcı güç kaynaklarına başvurdukları sonucuna ulaşılmıştır. Katılımcı öğretmenler okul müdürlerinin "çoğunlukla" uzmanlık gücü ve yasal güç kullandıklarını belirtmişlerdir. Bunları ödül gücü, uzmanlık gücü ve karizmatik güç izlemektedir. Araştırma bulguları bu konuda yapılmış başka araştırma sonuçlarıyla paralellik göstermektedir. Çeşitli araştırmacılar tarafından yürütülen çalışmalarda benzer şekilde yasal güç ve uzmanlık gücü yöneticilerin en sık kullandıkları güç kaynakları olarak tespit edilmiştir (Altınkurt ve Yılmaz, 2012; Deniz ve Çolak, 2008; Meydan ve Polat, 2010)

Öğretmen görüşlerinin özellikle uzmanlık gücü, ödül gücü ve karizma gücü alt boyutlarında bu sonucu vermiş olması olumlu ve istendik bir tablo olarak değerlendirilebilir. Çalışmada müdürlerin en çok uzmanlık gücünü kullandıkları sonucuna ulaşılmış olması bir yönüyle olumlu ve istendik bir tablo olarak değerlendirilebilir Yöneticiler bu güce başvurarak astları etkilediklerinde, çalışanlar yöneticinin daha iyi bildiğini, haklı olduğunu düşünerek harekete geçerler. Çalışanlar için yönetici bilgili ve birikimli bir liderdir ve ona uymak herkesin yararınadır. Çünkü yöneticinin sahip olduğu bilgi önemli bir güçtür (Bayrak, 2011). Uzmanlık gücü başka bir açıdan da değerlendirilebilir. Buna göre uzmanlık gücüne çok başvuran yöneticiler görev yönelimlidir (Birgi, 2006). Görev yönelimli yöneticiler daha çok yapılan işe odaklanırlar. Sonuca bakan bu tür yöneticiler, süreçteki gayretleri ve katkıyı gözden kaçırabilirler. Daha da kötüsü görev odaklı yöneticiler çalışanları, ihtiyaç ve önceliklerini göz ardı edebilirler. Uzmanlık gücünde küçük de olsa bu risk vardır.

Çalışmada müdürlerin uzmanlık gücüne yakın bir oranda ve ikinci sırada yasal güce başvurdukları sonucu ise olumsuz değerlendirilebilecek bir durumdur. Çünkü yöneticilerin sadece temsil ettikleri makamın kendilerine verdiği yasal yetkilere dayalı olarak çalışanları harekete geçirmeleri çağdaş yönetim ilkeleri açısından istendik değildir. Kaynağını bulunulan pozisyonun sağladığı resmi haktan alan (Faeth, 2004; Kırel, 2013) ve otoriteyi temsil eden yasal güçte astlar yöneticinin emir verme yetkisinin ve kendilerinin de uyma zorunluluğunun olduğunu bilirler. Müdürün talimatlarını sadece amirleri olduğu için yerine getiriler. Yasal gücün yoğun kullanımı; örgütte direnme, çatışma, iş doyumsuzluğu riski taşır (Altınkurt ve Yılmaz, 2012).

Öğretmenler çoğunlukla müdürlerin başarılı çalışanları takdir ettikleri, ödüllendirmede adaletli davrandıkları, yaratıcı ve okul yararına düşünceleri savundukları yaklaşımını yansıtan ödül gücünü kullandıkları görüşüne katılmışlardır. Ödül gücünün çoğunlukla kullanılması okullarda demokratik bir ortamın olduğuna dair önemli bir ipucudur. Ancak; zorlayıcı güçten 
sonra en az tercih edilen güç kaynăgı olması önemli bir bulgu olarak dikkat çekmektedir. Alanyazın incelendiğinde, farklı çalışmalarda yöneticilerin ödül gücüne başvurma düzeyleri açısından elde edilen sonuçlar da değişebilmektedir. Özaslan ve Gürsele göre (2008) öğretim elemanları bölüm ve anabilim dalı başkanlarının örgütsel güç kaynaklarından en çok ödül gücüne başvurdukları görüşündedirler. Açıalın (1993) ise öğretmen görüşlerine göre müdürlerin ödül gücüne başvurma sıklığının nadiren düzeyinde olduğunu ortaya koymuştur. Ayrıca Titrek ve Zafer (2009) özel ilköğretim okulu yöneticilerinin kamu okullarına göre ödül gücünü daha yeterli kullandıkları sonucuna ulaşmıştır.

Katılımc1 öğretmenler, okul müdürlerinin zorlayıcı gücünü nadiren kullanıldığı görüşündedirler. Ödül gücünün zıttı olan zorlayıcı gücün aşırı kullanımı çalışanları sürekli baskı altında hissettirebilir. Bu durum kendilerini sürekli olarak baskı ve cezalandırılma tehdidi altında hissetmedikleri şeklinde yorumlanabilir. Katz ve Kahn’a (1977) göre yasal güç tek başına çalışanların örgütsel bağllı̆ğını arttırmaya yeterli değildir. Yukl (1989) ise yetkin yöneticilerin formal güçlerinden daha çok informal etkileme becerilerini kullandıklarını, gelişmiş sosyal becerilere, katılımcı ve işbirlikçi özelliklere sahip olduklarını belirtmiştir (Akt. Altınkurt ve Yilmaz, 2012).

Araştırmaya katılan ilkokul öğretmenleri ortaokul öğretmenlerine göre müdürlerin yasal ve uzmanlık güçlerine daha sık başvurduklarını düşünmektedirler. Müdürlerin güç kullanım düzeylerinin branş değişkenine göre farklılaşmasına bakıldığında branş öğretmenlerinin yasal güç, ödül gücü, uzmanlık gücü ve karizmatik güç kaynaklarının daha sık kullanıldığını düşündükleri görülmektedir. İlköğretim okullarında temel eğitimin ilk safhası olan dört yıllık eğitim sınıf öğretmenleri tarafından verilir. Yabancı Dil ve Din Kültürü dersleri dışında öğrenciler tüm derslerini sınıf öğretmenlerinden alırlar. Ortaokulların kadrosunun tamamı ise branş öğretmenlerinden oluşmaktadır ve bir tek sınıfın her bir branş dersini farklı bir öğretmen yürütmektedir. Dolayısıyla, ortaokul öğretmenlerinin birbirleriyle etkileşiminin daha yoğun olması beklenir. Aynı şekilde sınıf öğretmenleri genellikle sadece kendi sınıfında eğitimine devam eden öğrenciler ile yoğun şekilde etkileşime geçerken, ortaokul öğretmenlerinin ders verdiği sınıflardaki tüm öğrencilerden aynı ölçüde sorumludur. Bununla birlikte ortaokul öğretmenlerinin eğitim verdiği öğrencilerin diğer branş öğretmenleri ile de eşgüdümlü olarak çalışması ve öğrenci gelişimlerini beraber değerlendirmeleri beklenir. Şube Öğretmenler Kurulu Toplantısı bu duruma örnek olarak verilebilir. Bulgular ışı̆̆ında incelendiğinde, ortaokul öğretmenlerinin ilkokul öğretmenlerine göre müdürlerin daha fazla yasal ve uzmanlık gücüne başvurdukları görüşü, müdürlerin etkileşimin daha yoğun yaşandığı ve koordinasyona daha çok ihtiyaç duyulan ortaokullarda okulu amaçlar doğrultusunda yönetebilmek için bu güç kaynaklarına daha sık başvurma gereği hissetmeleri ile açıklanabilir. Açıkalın (1993) okul türüne göre güç kullanımındaki farklılaşma, farklı okul türlerinde farklı gelenek ve değerler oluşturmasindan da kaynaklanabileceğini ifade etmektedir.

Kıdem değişkenine göre bulgular incelendiğinde 1-2 yıl kıdeme sahip öğretmenler, müdürlerin yasal güçlerine daha sık başvurdukları görüşündedirler. Bu görüşün kaynağını oluşturan etmenlerin, okul müdürlerinin göreve yeni başlamışöğretmenlere yasal gücünü daha 
fazla hissettirerek resmi prosedüre uymaları konusunda uyarı ve hatırlatmalarda bulunmaları olduğu düşünülebilir. Farklı bir bakış açısıyla üniversiteden yeni mezun olmuş ve yeni atanmış öğretmenler üniversitelerin görece daha serbest ve özgürlükçü havasını etkisinde kalarak öğretmenlik mesleğinin ilk yıllarında kendilerini daha fazla yasal güce maruz kalmış hissediyor olabilirler. Benzer şekilde kıdem yılı 1-2 yıl olan öğretmenler okul müdürlerinin ödül gücünü daha sık kullandığını düşünmektedirler. Bu iki bulgu beraber düşünüldüğünde, okul müdürlerinin bu davranışı göreve yeni başlamış genç ve dinamik öğretmenlere daha fazla görev verdiklerini ve aldıkları görevi hakkıyla yerine getiren öğretmenlere de daha fazla ödül gücünü kullandığı şeklinde yorumlanabilir. Bu şekilde görevlerinde kısmen daha az tecrübeli öğretmenlerin hem öğretmenlik mesleğinin yasal süreçlerini daha iyi öğrendikleri hem de okula sağladıkları katkılardan dolayı müdür tarafından ödüllendirildikleri düşüncesiyle bu davranışlarının pekiştiği düşünülebilir.

Müdürlerin güç tercihleri hakkındaki öğretmen görüşlerinin cinsiyet değişkenine göre farklılaşmadığı ve hem erkek hem kadın öğretmenlerin bu konuda benzer fikirlere sahip oldukları görülmektedir. Alanyazında cinsiyet değişkeninin belirleyici olmadığını ortaya koyan farklı çalı̧̧malar da mevcuttur (Çalışır, 2008; Altınkurt ve Yılmaz, 2012; Titrek ve Zafer, 2009; Helvacı ve Kayalı, 2011). Bu bulgulara ışığında, cinsiyet değişkeninin müdürlerin güç kullanımı hakkında öğretmen görüşleri üzerinde belirleyici bir etkisi olmadığı söylenebilir.

Araştırma da Siirt ve Van illerinden katılan öğretmenlerin, müdürlerin güç kaynaklarını kullanma düzeyleri hakkında benzer fikirler belirttikleri görülmüștür. Diğer bir deyişle Van ve Siirt illerinde görev yapan ilköğretim okulu öğretmenlerinin müdürlerin güç kullanım düzeyleri hakkında benzer görüşlere sahip oldukları söylenebilir. Araştırmanın yapıldığı iki ilin sosyokültürel ve coğrafi yakınlıkları böyle bir sonucun ortaya çıkmasında etkili olmuş olabilir.

Sonuç olarak okul müdürlerinin güç kaynaklarını kullanım tercihleri ve sıklıklarına ilişkin olumlu noktalar tespit edilmekle beraber geliştirilmesi gereken noktaların olduğu söylenebilir. Okul müdürleri en çok uzmanlık ve yasal güçlerine başvurmaktadırlar. Yasal gücün aşırı kullanımı baskı olarak algılanabilmekte ve daha sınırlı düzeyde kullanılması tavsiye edilmemektedir (Altınkurt ve Yılmaz, 2012). Zorlayıcı gücün en az tercih edilen güç kaynağı olarak ortaya çıkması bir bakıma olumlu olarak görülse de orta düzeyde kullanılan zorlayıcı gücün bile öğretmenler üzerinde olumsuz etkiler oluşturabileceği unutulmamalıdır. Bununla birlikte okul müdürleri ödül gücü, karizma gücü, uzmanlık gücü gibi öğretmenleri harekete geçirmede onların içsel motivasyonlarından da yararlanan güç kaynaklarına başvurarak okulda baskıcı olmayan ve motive edici bir iklim oluşturmaya çalışmaktadırlar. Ayrıca okul müdürleri her öğretmenin aynı şekilde etkilenemeyeceğinin bilinciyle farklı güç kaynaklarına başvurmakta ve kullanımı çok tavsiye edilmeyen zorlayıcı güç dışındaki tüm güç kaynaklarına okul yönetimlerinde çokça yer vermektedirler.

Öğretmenleri etkilemelerinin ve onları okulun amaçlarına uygun olarak çalışmalarını sağlamanın temel yollarından biri müdürlerin güç kaynaklarını doğru bir şekilde bilmeleri ve kullanabilmeleridir. Bu doğrultuda okul müdürlerinin örgütsel güç kaynaklarının farkında 
olmaları ve bu güç kaynaklarını daha iyi tanıyıp daha iyi kullanabilmeleri için pratik bilgiler ve somut örnekler sunan hizmet içi eğitim veya seminerler düzenlenebilir. Ayrıca, okul müdürlerinin de dahil edildiği ve konuya daha derinlemesine bir bakış açısı sağlayacak nitel ve nicel yöntemlerin bir arada kullanıldığı araştırmaların yapılması ilgili literatüre katkı sunacaktır. 


\section{Kaynaklar}

Açıkalın, Ş. (1993). Öğretmenlerin okul müdürlerini etkileme güçleri (Ankara ili örneği). Hacettepe Üniversitesi Eğitim Fakültesi Dergisi. 9: 183-192.

Altınkurt, Y. ve Yılmaz, K. (2012). Okul yöneticilerinin kullandıkları güç kaynakları ile öğretmenlerin iş doyumu arasındaki ilişki. Kastamonu Eğitim Dergisi. 20(2): 385-402.

Altınkurt, Y. ve Yılmaz, K. (2013). Okullarda örgütsel güç ölçeğinin geliştirilmesi: geçerlik ve güvenirlik çalışması. E-Uluslararası Eğitim Araştırmaları Dergisi. 4(4): 1-17.

Aslanargun, E. (2009). İlköğretim ve lise müdürlerinin okul yönetiminde kullandıkları güç türleri. (Yayınlanmamış Doktora Tezi). Ankara Üniversitesi Eğitim Bilimleri Enstitüsü, Ankara.

Bakan, İ. ve Büyükbeşe, T. (2010). Liderlik türleri ve güç kaynaklarına ilişkin mevcut gelecek durum karşılaştırması: eğitim kurumu yöneticilerinin algılarına dayalı bir alan araştırması. Karamanoğlu Mehmetbey Üniversitesi Sosyal ve Ekonomik Araștırmalar Dergisi. 12(19), 73-84.

Balcı, A. (2010). Açıklamalı eğitim yönetimi terimleri sözlüğü. Ankara: Pegem Akademi.

Başaran, İ. E. (2004). Yönetimde insan ilişkileri. Ankara: Nobel Yayıncılık.

Bayrak, S. (2001). Yönetimde bir ihmal konusu olarak güç ve güç yönetimi-II-. Süleyman Demirel Üniversitesi İktisadi ve İdari Bilimler Fakültesi Dergisi, 6(1), 23-42.

Bayraktaroğlu, S. (2000). Klasik örgütsel güç kuramlarından Clegg'in “Güç Devreleri” yaklaşımına. Bilgi Dergisi, 2, 109-122.

Bierstedt, R. (1950). An analysis of social power. American Sociological Review, 15(6), 730-738. http://www. jstor.org/stable/2086605. Erişim tarihi 15 Kasım 2015.

Birgi, B. (2006). Eğitimde yönetsel gücün etkili kullanımı. http://kutuphanem.bilgievi. gen.tr/indir. aspx?id=6772. 20.03.2014.

Büyüköztürk, Ş. Çakmak, E. K., Akgün, Ö. E., Karadeniz, Ş., Demirel F. (2013). Bilimsel araştırma yöntemleri. Ankara: Pegem A. Yayıncilık.

Can, N. ve Çelikten, M. (2000). Alt düzey personelin güç kaynakları (Erciyes Üniversitesi örneği). Kuram ve Uygulamada Eğitim Yönetimi Dergisi, 22(22), 269-290.

Cross, D.C. (1986). The relationship between the bases of power of the principal and indicators of school effectiveness. (Yayınlanmamıs Doktora Tezi). The School of Graduate Studies and Research of the University of Ottowa, Ottowa, Canada.

Çalışır, M. (2008). Mamak ilçesi ilköğretim okulu yöneticilerinin görüşlerine göre okul müdürlerinin kullandıkları yetki türü ve düzeyleri. (Yayınlanmamış Yüksek Lisans Tezi). Ankara Üniversitesi Eğitim Bilimleri Enstitüsü, Ankara.

Dahl, R. A. (1957). The concept of power. Behavioral Science. 2 (3): 201-214.

Deniz, M. ve Çolak, M. (2008). Örgütlerde gücün kullanımı ve bir araştırma. Elektronik Sosyal Bilimler Dergisi. 7 (23): 304-332.

English, F. W. (1992). Educational administration. New York: Harper Collins Publishers.

Erchul, W. P. ve Raven, B. H. (1997). Social power in school consultation: a contemporary view of French and Raven's bases of power model. Journal of School Psychology. 35(2): 137-171.

Faeth, M., A. (2004). Power, authority and influence: A comparative study of behavioural influence tactics used by lay and ordained leaders in Episcopal Church. (Unpublished Doctorate Thesis). Virginia Polytechnic Institute and State University, Virginia.

Fiske, S. T., ve Berdahl, J. (2007). Social power. Social psychology: Handbook of basic principles, 2, 678-692. 
Gong, J. (2006). Power. F. W. English (Ed.) Encyclopedia of Educational Leadership and Administration. New Delhi, India: Sage Publication.

Helvacı, A. ve Kayalı, M. (2011). Okul müdürlerinin kullandıkları güç kaynaklarının bazı değişkenler açısından incelenmesi (Uşak ili örneği). Mehmet Akif Ersoy Üniversitesi Eğitim Fakültesi Dergisi. 11 (22): 255-279.

Karasar, N. (2008). Bilimsel araştırma yöntemleri. Ankara: Nobel Yayıncılık.

Kırel, A. Ç. (1996). Örgütlerde güç ve politik davranışlar. E. Özkalp (Ed.) Örgütsel davranış içinde. Eskişehir: Anadolu Üniversitesi Web-ofset.

Kırel, A. Ç. (2013). Organizasyonlarda güç politika ve çatışma. A., Ç. Kırel (Ed.) Organizasyonlarda davranış içinde. Eskişehir: Anadolu Üniversitesi Web-ofset.

Koşar, S. ve Çalık, T. (2011). Okul öneticilerinin yönetimde gücü kullanma stilleri ile örgüt kültürü arasındaki ilişki. Kuram ve Uygulamada Eğitim Bilimleri Dergisi, 17(4), 581-603.

Lunenburg, F. C. (2012). Power and leadership: An influence process. International Journal of Management, Business and Administration, 15(1), 1-9.

Meydan, C. H. ve Polat, M. (2010). Liderin güç kaynakları üzerine kültürel anlamda bir araştırma. Ankara Üniversitesi Siyasal Bilimler Fakültesi Dergisi. 65 (4): 123-140.

Özaslan G. ve Gürsel, M. (2008). Eğitim yöneticilerinin güç tipi tercihlerinin tercihleri. Selçuk Üniversitesi Ahmet Keleşoğlu Eğitim Fakültesi Dergisi. 25: 351-370.

Pfeffer, J. (1992). Managing with Power. Boston, Mass.: Harvard Business School Press.

Pfeffer, J. (2010). Power: Why some people have it and others don't. HarperBusiness.

Raven, B. H. (2008) The bases of power and the power/ interaction model of interpersonal influence. The Society for the Psychological Study of Social Issues. 8(1): 1-22.

Robbins S. P. ve Judge, T. A. (2013). Örgütsel davranış. (İ. Erdem, Çev.). Ankara: Nobel Akademik Yayıncılık.

Rollinson, D. ve Broadfield, A. (2002). Organisational behaviour and analysis. Edinburg: Pearson

Steers, R. M. (1981). Introduction to organizational behavior. Glenview, Illinois: Scott, Foresman and Company.

Şimşek, M. Ş. (2002). Yönetim ve organizasyon. Konya: Günay Ofset.

Titrek, O. ve Zafer, D. (2009). İlköğretim okulu yöneticilerinin kullandıkları örgütsel güç kaynaklarına ilişkin öğretmen görüşleri. Kuram ve Uygulamada Eğitim Yönetimi. 15 (60): 657-674.

Wrong, D., H. (1968). Some problems in defining social power. The American Journal of Sociology, 73(6), 673,686. http://documents.mx/documents/dennis-h-wrong-some-problems-in-defining-socialpower.html. Erişim tarihi 15 Kasım 2015. 
